\title{
Women as Shari'ah Court Judges With Reference to Judicial Creativity: A Comparative Study of Malaysia and Indonesia
}

\author{
Ramizah Wan Muhammad \\ Ahmad Ibrahim Kulliyyah of Laws (IIUM), Kuala Lumpur, Malaysia \\ Ahmad Muslim Rozlan \\ Tetuan Sri, Ling \& Associates, Kuala Lumpur, Malaysia
}

\begin{abstract}
Woman and shari'ah court have been discussed in many literature works for a long time. There are juristic views on the eligibility of a woman to hold the post of a judgeship in Islamic judiciary in which the majority of the Muslim jurists who opined that they are not qualified enough to hold the post and others said that they are qualified but subject to certain and limited jurisdictions. As a result of the juristic views, there are also fatwas about the permissibility and non-permissibility of a woman to hold a post of shari'ah court judge including Malaysia. Despite the non-unanimous decision on this issue, there are some states in Malaysia, such as Selangor and Federal Territories which have appointed a woman to be a judge. Comparing this issue with Indonesia including Aceh, one could see that Indonesia is in the forefront in acknowledging woman in the Islamic judiciary. The paper is an attempt to see how this issue is dealt with between these two countries by looking into the related laws governing the qualifications of a judge and the challenges that a woman judge faces in the two countries.
\end{abstract}

Keywords: shari'ah court, women, law, Malaysia, Indonesia

\section{Introduction}

Islamic judiciary is one of the indispensable institutions in the constitutional framework of one's country. It becomes one of the important bases other than executive and legislature in the constitution such as in the Federal Constitution of Malaysia 1957. In Islam, the judiciary could become an independent organ in administering the law or could be a branch of the executive power, yet it is an independent body. Islamic judiciary is an independent institution which consists of a number of judicial officers, such as prosecutors, lawyers, mediators, enforcement officers, and judges. Judicial systems in most of the colonized countries have been shaped by their particular history, political system, social structure, dominant religion, economic performance, and other factors. Indonesia and Malaysia are among the countries which have been colonized by British and Dutch respectively. In judicial system, the Malaysia and Indonesia have a dual legal system to cater the needs of multi-religious society. The dual legal system is the existence of two types of courts: civil and shari'ah court. In Indonesia, shari'ah court is called religious court.

Ramizah Wan Muhammad, Department of Islamic Law, Ahmad Ibrahim Kulliyyah of Laws (IIUM), Kuala Lumpur, Malaysia. Ahmad Muslim Rozlan, advocate \& solicitor, Tetuan Sri, Ling \& Associates, Kuala Lumpur, Malaysia. 


\section{Qualification of a Judge in Islam and Malaysia}

In the legal texts, Qur'an and Sunnah, there are no specific qualifications for a person to be a judge. There are some hadith that laid down the etiquettes to be a judge, such as prior giving a decision, a judge must hear from parties and does not give a decision while in a state of anger. However, in terms of selection of judges, it is actually up to the knowledge of the caliph or authority that is in charge of appointing judges.

During the period of the Prophet, Khulafa' al-Rashidun, Umayyah, and Abbasiyyah, the selections were made based on two conditions, which are:

(1) Through the utilization of specific knowledge of the caliph himself, for instance, any man who is widely known for his ability and experience in settling cases previously, such as the appointment of Ali Bin, Abu Talib, and Abdullah Ibn Mas'ud;

(2) By way of examination and interview in order to assess the capability of the person who is intended to be appointed.

As a result of that, the qualifications to be appointed as a judge are based on the ijtihad of Muslim jurists, especially on the gender issue. It is believed that a woman is excluded from holding the post of a judge based on the custom (Prakash, 2002) and norms of one's society.

There are other scholars who have laid down the following conditions of a judge:

(1) Muslim;

(2) Baligh;

(3) Sound mind;

(4) Free;

(5) Male;

(6) Adil;

(7) Understands the meaning of the verses of the Qur'an and Sunnah;

(8) Acquainted with ijma' of ulama' and the ikhtilaf between them;

(9) Familiar with the Arabic language;

(10) Knows the basis of qiyas;

(11) Possesses perfect sight and hearing.

The criteria for No. 7 to 10 can be translated that a person must be learned in Islamic law. In Malaysia, this has been provided under Section 41 (2) (b) (ii) of the Administration of Islamic Law Federal Territories 1993. Someone who is learned in Islamic law can be defined as someone who is knowledgeable in the Arabic language, Islamic jurisprudence, fiqh, hadith, Qur'an, and other aspects of Islamic law. On top of that, being a learned man, he must also have the judicial creativity in interpreting the legal provisions and applying the law according to the facts of the case. To be a learned person, one should not limit to the academic qualifications but rather to look at his ability to look the hidden areas in the case.

\section{Judicial Creativity or Judicial Activism}

One of the reputable qualities which should be possessed by a judge, irrespective of gender, is the ability to critically analyse the relevant law and apply it into the facts of a case in a creative manner so as to arrive at a just and fair decision. This ability has been referred to by some scholars, if not all, as judicial activism or judicial creativity. In Islam, judicial creativity could only be achieved if a person is knowledgeable on divine revelation and traditions of the Prophet SAW as well as his companions (Wan Muhammad, 2009). 
Chief Judge Frank Easterbrook had referred to judicial activism as "that notoriously slippery term" (Easterbrook, 2002, p. 1401). Hishamudin was also of the opinion that judicial activism on certain occasions has been associated with negative connotations and poorly understood by many ${ }^{1}$. The ambiguity of the term "judicial activism" is further stressed upon by William P. Marshall (2002) in "Conservatives and the Seven Sins of Judicial Activism" when he made the following remarks:

Any discussion of conservative judicial activism is immediately beset by two threshold definitional problems: the meaning of conservative and judicial activism. Neither term is free from ambiguity. ${ }^{2}$

However, Kmiec observed that although most scholars would agree that the doctrine of judicial activism is indeed slippery, some scholars have suggested that this doctrine, in certain circumstances or contexts, is not always a bad thing (Kmiec, 2004). Despite being equivocal in meaning, the author has emerged with five characteristics which might constitute judicial activism, inter alia: (1) invalidation of the arguably constitutional actions of other branches, (2) failure to adhere to precedent, (3) judicial legislation, (4) departures from the accepted interpretive methodology, and (5) result-oriented judging (Kmiec, 2004).

Apart from the characteristics of judicial activism as propounded by Kmiec, Lori A. Ringhand (2007) in "Judicial activism: An empirical examination of voting behaviour on the rehnquist natural court" had also defined judicial activism as a justice's willingness to invalidate federal legislation, to invalidate state legislation and to overturn precedent.

Whereas in Malaysia, an attempt to define the doctrine of judicial activism has been made by Justice Mohd Hishamudin Yunus (the then Malaysian Court of Appeal Judge). In his article, he clearly stated that he did not propose to offer a definition of the doctrine of judicial activism, he does, however, say the followings:

All that I wish to say is simply that "judicial activism” is a term that describes a judicial decision that is creative, that breathes life into the law; a decision that involves inductive reasoning, that is positive and takes into account the social needs of time, whilst at the same time paying heed to the principles of justice and the legal and constitutional framework within which the decision is made. (Hishamudin Yunus, 2011, p. 167)

While under the civil law, the definition given to this doctrine of judicial activism is without certainty and may differ from scholars to scholars, the authors believe that judicial activism is the ability of a judge in interpreting or applying the law at hand in a creative and innovative manner with less rigidity and more flexibility when interpreting the provisions of the law in order to arrive at the right decision.

Whereas under the shari'ah law, this judicial activism or judicial creativity is known by the Muslim scholars as ijtihad. Ijtihad is literally an effort and endeavour undertaken by Muslim scholars for attaining some objective or the truth of knowledge. While in Islamic legal terminology, it means the process of deriving the laws of shari'ah from its sources. Abdur Rahman I. Doi (1984) stated that the Arabic word of ijtihad literally means an effort or an exercise to arrive at one's own judgment. Whereas in its widest sense, it means the use of human reason in the elaboration and explanation of the shari'ah law. It covers a variety of mental process ranging from the interpretation of texts of the Qur'an. The method by which the principles established by the Qur'an, Sunnah $^{3}$, and ijma ${ }^{, 4}$ are to be extended and applied as a solution to the new problems which have not

\footnotetext{
1 Mohd Hishamudin Yunus, op. cit., pg. 166.

2 Ibid.

3 An Arabic word which literally means "method", which was applied by the Prophet Muhammad S.A.W. as a legal term comprising what he said, did, prohibited and allowed.

${ }^{4}$ A consensus opinion of the companions of the Prophet Muhammad S.A.W. (sahabah) and the agreement reached on the decisions taken by the learned muftis or the jurists on various Islamic matters.
} 
been regulated before. Therefore, ijtihad is an exercise of one's reasoning to arrive at a logical conclusion on a legal issue done by the jurists to deduce a conclusion as to the effectiveness of a legal precept in Islam (Doi, 1984).

According to Taha Jabir Al-Alwani (1993), ijtihad may be described as a creative but disciplined intellectual effort to derive legal rulings from those sources while taking into consideration the variables imposed by the fluctuating circumstances of Muslim society. The author further states that ijtihad begins with a single word of iqra' in which Islam starts to nurture Muslims that by reading the Qur'an and other types of literature, it would allow them to formulate ideas and arrive at the conclusion that would help man understand himself and the world around him (Al-Alwani, 1993).

Whereas ijtihad, according to Said Ramadan (1987), literally means to exert oneself. The starting point where one could exercise ijtihad is when the legal texts from Qur'an and Sunnah are absent and it may only operate so far it does not contravene the Qur'an and Sunnah.

The Islamic legal term of ijtihad means "independent reasoning" as opposed to taqlid (imitation). It is one of the four sources of Sunni law and is utilized where the Qur'an and Sunnah (the first two sources) are silent. It requires a thorough knowledge of theology, revealed texts, and legal theory (usul al-fiqh); a sophisticated capacity for legal reasoning; and a thorough knowledge of Arabic. It is considered a required religious duty for those qualified to perform it. It should be practised by means of analogical or syllogistic reasoning (qiyas). Its results may not contradict the Qur'an, and it may not be used in cases where consensus (ijma') has been reached, according to many scholars. Sunnis believe ijtihad is fallible since more than one interpretation of a legal issue is possible. ${ }^{5}$

Based on those definitions of ijtihad, one could conclude that the exercise of ijtihad or judicial activism in Islam is allowed, and sometimes commendable, in situations where there are no legal texts available from the Qur'an and Sunnah to regulate such matters. Hence, the Muslim jurists must exercise their utmost reasoning in order to arrive at a logical conclusion on a legal issue especially in this modern era where people had discovered and encountered all sorts of new technologies and problems which could not be found in any previous civilisations.

Since there are two separate sets of legal systems applicable in Malaysia, i.e., a civil legal system based on the common laws of the United Kingdom as well as shari'ah legal system based on the Islamic laws, the authors believe it is therefore very significant for this paper to discuss the application of judicial activism or judicial creativity from both perspectives.

In contrast with judicial activism, judicial restraint is a situation where the judges refuse to broaden the context or meaning of certain words contained in the provisions of the law. Instead of interpreting the provisions of the law in a broad manner, the judge applies the literal approach in his or her interpretation of the law.

While judicial activism generally connotes judges' creativity in interpreting provisions, judicial restraint, on the other hand, entails an exact opposite meaning to judicial activism. By adopting judicial restraint, judges are expected to refrain themselves from interpreting provisions in a broad and liberal manner. Some scholars have argued that it is not the role of unelected judges to thwart people's will and overturn the duly enacted legislation.

5 “Ijtihad”, Oxford Islamic Studies Online, 14th January, 2018, http://www.oxfordislamicstudies.com/. 
According to Pinelli (2007), the more a judge feels free, in circumstances such to give the text further meanings, the more he is considered an "activist". Conversely, the more a judge abstains himself from giving the text those meanings, the more he is deemed to abide a "restraint-based" approach.

Whereas according to Shentob (2001), judicial restraint is when judges should defer to executive or legislative measures unless these measures in themselves are clearly unconstitutional or have a long political or academic pedigree.

One would inevitably wonder as to why there is a need for a judge to exercise this judicial activism in their decision making. A rigid application of literal approach by judges in interpreting the provisions of the law sometimes has caused absurdities and injustices to the parties concerned. Judges are the final arbiters of any disputes confronted by parties, therefore, his or her decision, without a doubt, must also be seen to have caused justice to the disputed parties. Therefore in order to avoid injustice and absurdity, sometimes, judges must adopt creative thinking and analytical reasoning in applying the law at hand so as to arrive at a just and fair decision. More often than not, by applying judicial activism the judges will be able to arrive at a just decision whenever they encountered a rigid law.

\section{The Practice of Judicial Activism by the Civil Court and Shari'ah Court in Malaysia}

Under the Malaysian civil legal system, the adoption of judicial activism by civil judges can be seen immensely in cases involving interpretation of constitutional provisions especially that of fundamental liberty to life as enshrined under Article 5 of the Malaysian Federal Constitution. In Malaysian Federal Constitution, Article 5 (1) provides as follows:

No person shall be deprived of his life or personal liberty saves in accordance with the law.

Article 5 clearly provides that no person can be deprived of his or her life except in accordance with the existing laws legislated in Malaysia, such as death penalty. It clearly protects one's life as one of the most fundamental liberties, nevertheless if judges should adopt literal meaning of the above-mentioned provisional constitution, one could not help but state that this Article 5 only provides protection to human's life and no other.

Nevertheless, the inclination of Malaysian judges in interpreting Article 5 is that of liberal approach. Malaysian judges, in so many cases, have creatively interpreted the right to "life" in Article 5 as to include the right to livelihood, the right to have a reputation, the right to have a fair trial, the right to teach one's children with religion, and the right to have a reasonable healthy and pollution free environment. This creative interpretation given by judges has, in a way, avoided the Article 5 of the Malaysian Federal Constitution from being rigid and inflexible.

This can be seen in the case of Hong Leong Equipment Sdn Bhd v Liew Fook Chuan, ${ }^{6}$ where the Court of Appeal in this case, by referring to the case of Tan Tek Seng, has held that the right to livelihood is one of those fundamental liberties guaranteed by Part II of the Federal Constitution and therefore falls under constitutional protection. In 1998, the Court of Appeal in the case of Sugumar Balakrishnan v Pengarah Imigresen Negeri Sabah \& Anor $^{7}$ has also held that the word "life" in Article 5 of the Malaysian Federal Constitution is not limited to a mere existence but is a wide concept that must receive a broad and liberal interpretation. ${ }^{8}$

\footnotetext{
${ }^{6}$ [1996] 1 MLJ 481.

7 [1998] 3 MLJ 289.

8 Ibid, p. 305.
} 
Furthermore, the Federal Court in the case of Shamim Reza Bin Abdul Samad also, in agreement with its earlier majority decision in the case of Badan Peguam Malaysia v Kerajaan Malaysia [2008] 2 MLJ 285 has held that the expression "life" under Article 5 must be given a wide meaning and interpreted generously. ${ }^{9}$ Thus, the Malaysian judiciary in this regard has been consistently adopting the liberal interpretation of the word "life" under Article 5.

In accordance with the principles of interpretation discussed and accepted by this Court in Badan Peguam Malaysia v Kerajaan Malaysia [2008] 2 MLJ 285, the expressions "life" and "personal liberty" must be interpreted generously and given a wide meaning. ${ }^{10}$

The court in the case of Lembaga Tatatertib Perkhidmatan Awam v Utra Badi ${ }^{11}$ has also held that the right to life includes the right to livelihood. Interestingly enough, the court in this case has further held that the right to life equally includes the right to reputation.

The fundamental right to life has also been held by the court in Lee Kwan Woh v Public Prosecutor as to include the rights of an accused in criminal proceedings to receive a fair trial and just decision based on facts from an impartial tribunal. The court has also held that this right can only be deprived by a state action that is both fair in point of procedure as well as substance. ${ }^{12}$ Since the appellant (the accused) in this appeal was not allowed by the High Court to make a submission of no case at the closure of the prosecution's case, it is therefore inevitable that his right to fair trial was admittedly deprived by the High Court. ${ }^{13}$

The court recently, to a certain extent, has also included a native customary right as a part and parcel of the right to livelihood as decided in the case of Nor Anak Nyawai v Borneo Pulp Plantation Sdn Bhd \& Ors. ${ }^{14}$ The same stand has been taken by the High Court in the case of Andawan Bin Ansapi \& Ors v Public Prosecutor ${ }^{15}$ where the court made the following remarks:

It has also been said "native customary rights" equates to "right to life” under Article 5 of the Federal Constitution. In the circumstance, I hold that the Magistrate was wrong in saying native customary rights cannot be established in a Forest Reserve. ${ }^{16}$

In reference of Kebing Wan \& Anor v Lembaga Pembangunan Dan Lindungan Tanah \& Ors, ${ }^{17}$ the High Court in this case fascinatingly held that the indefeasibility of title in any land will be subjected to native customary rights. In other words, native customary rights supersede any rights conferred by the statute. The exact wordings of Justice David Wong Dak Wah (as he then was) are reproduced as follows:

... Native customary rights, as held by the apex Court in the land in Madeli case, cannot be extinguished by any settlement of any foreign race in the country. In the words of Chief Justice of the Federal Court in Madeli case, the Crown may "acquire a radical title or ultimate title to the land but not absolute beneficial ownership of the land as such right or interest is subject to any native rights over such land”. In simple language, native customary rights, once established, supersede whatever rights one gets from the Statute for the simple reason they existed before the legislation. ${ }^{18}$

\footnotetext{
9 Supra.

10 Ibid, p. 475.

11 [2000] 3 MLJ 281.

12 [2009] 5 MLJ 301, p. 315.

13 Ibid, p. 316.

14 [2001] 6 MLJ 241.

15 [2011] MLJU 224.

16 Ibid, p. 3.

17 [2012] MLJU 1284.

18 Ibid, p. 10.
} 
The court has also held that the right to freedom of life includes the presumption of innocence on the part of the accused person, aside from the right of the accused person to have the criminal charge to be proven beyond reasonable doubt. This can be seen in the case of Public Prosecutor v Gan Boon Aun \& Anor. ${ }^{19}$ The High Court in this case has held Section 122 (1) of the Securities Industry Act 1983 as unconstitutional for being in contravention with Articles 5 and 8 of the Federal Constitution. This impugned section deprived the accused person of the presumption of innocence and his right to have the prosecutor prove the criminal charge beyond reasonable doubt. ${ }^{20}$

Even though later on the Court of Appeal overturned the decision of the High Court in declaring the impugned Section 122 (1) of the Securities Industry Act 1983 as unconstitutional, it remains untouched that the presumption of innocence and the right of the accused to have his criminal charge to be proven beyond reasonable doubt are a part of the fundamental rights provided under Article 5 of the Malaysian Federal Constitution. $^{21}$

In 2013, the court has hurdled a step ahead by interpreting the term "life" as to include the right of parents to teach religion to their children. The best and only example for this would be the case of Indira Gandhi $a / p$ Mutho v. Pengarah Jabatan Agama Islam Perak \& $\mathrm{Ors}^{22}$, where the High Court in this case held that the term "life” would also encompass spiritual and religious aspects of life.

Indeed Art 11 is inextricably tied up with Art 5(1) of the Federal Constitution where no person shall be deprived of his life or personal liberty save in accordance with the law. "Life" has been understood to be more than just mere existence. It is not just physical life sustained by food but emotional, intellectual and spiritual as well; for man does not live by bread alone. The human person is not just mere body, but soul and spirit as well. It includes the right to choose one's religious beliefs and to teach one's religious beliefs to one's children. It encompasses life in all its fullness where the spiritual and religious aspects of one's life is concerned. After all, the first tenet of the Rukunegara declares "Belief in God". If the right to life extends to the right to livelihood as eloquently expressed His Lordship Gopal Sri Ram JCA (as he then was) in Tan Tek Seng v Suruhanjaya Perkhidmatan Pendidikan \& Anor [1996] 1 MLJ 261; [1996] 2 CLJ 771, then it surely must be extended to encompass the spiritual and religious aspects of life as well. ${ }^{23}$

Quite recently, the Court of Appeal Malaysia in Muhamad Juzaili Bin Mohd Khamis \& Ors v State Government of Negeri Sembilan \& Ors ${ }^{24}$ has reversed the decision of the High Court and held that Section 66 of the Shari'ah Criminal Enactment (Negeri Sembilan) 1992 unconstitutional as the impugned section is inconsistent with the right to life, as provided under Article 5 of the Malaysian Federal Constitution, since it puts the lives of the appellants in uncertainty, misery, and indignity as well as depriving the right of the appellants to livelihood and quality of life.

Section 66 of the said enactment provides an offence for a Muslim man who wears womanly attire or poses as the opposite gender. The appellants in this case had been repeatedly arrested, detained, and prosecuted by the religious authority for breaching Section 66 of said enactment. The same appellants had been diagnosed with the medical condition known as gender identity disorder (GID). Hishamudin Yunus JCA (as he then was) said as follows:

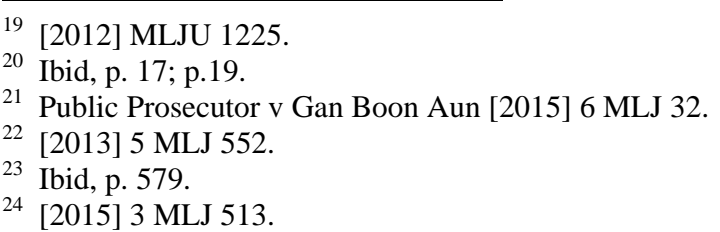


The very core identity of the appellants is criminalised solely on account of their gender identity. Learned counsel submitted that s 66 is irreconcilable with the existence of the appellants and all other GID sufferers. A more disturbing effect of s 66 is that it builds insecurity and vulnerability into the lives of the appellants and other Muslim male persons with GID. The existence of a law that punishes the gender expression of transsexuals, degrades and devalues persons with GID in our society. As such, s 66 directly affects the appellants' right to live with dignity, guaranteed by Art 5(1), by depriving them of their value and worth as members of our society.

We find merit in this argument. As long as s 66 is in force the appellants will continue to live in uncertainty, misery and indignity. They now come before this court in the hope that they may be able to live with dignity and be treated as equal citizens of this nation. ${ }^{25}$

However, the Federal Court on 8th October, 2015 reversed the decision of the Court of Appeal based on technicality issue, i.e., whether the High Court and the Court of Appeal in this case have jurisdiction to declare Section 66 of the Shari'ah Criminal Enactment (Negeri Sembilan) 1992 as unconstitutional and was thus void. It was held by the Federal Court that the High Court and Court of Appeal did not have jurisdiction under the Federal Constitution, especially under Article 4 (4), to declare an enactment passed by the state legislature or act passed by the parliament as unconstitutional and void. ${ }^{26}$

While judicial activism may be adopted immensely by civil judges in interpreting "life" in Article 5 of the Malaysian Federal Constitution, the same could not have been said to be the same in other interpretation of the constitutional provisions involving other fundamental liberties. Malaysian judges are not really consistent in adopting judicial activism whenever they have to deal with the rest of the constitutional provisions (Rozlan, 2017).

In comparison to the exercise of judicial activism adopted by the civil courts in Malaysia, the exercise of judicial activism or ijtihad by the shari'ah courts is scarce and very hard to find. Nevertheless, there are four cases where one could see the exercise of judicial activism by the shari'ah courts in Malaysia. The first case is the case of Aisyah Linda Xavier Bt Abdullah (2003), where in this case, Aisyah had contracted her marriage in Iran based on the Shi'ah school of law. Later on when she came back to Malaysia, she had applied to the shari'ah court to determine the validity of her marriage in Iran even though the Islamic law applicable in Malaysia is based on Sunni school of law, especially that of Shafi'e school of law. Evidence in a form of video recording, showing her marriage solemnization was brought before the shari'ah court and after taking into consideration of that evidence, the court held that her marriage has been properly solemnized according to Islamic law despite the fact that there was Order No. 8 of the Practice Direction of the shari'ah court pertaining to the marriage abroad. Despite acknowledging the noble effort of that Order No. 8 to standardize the judgment of all shari'ah court judges according to the fatwa issued in each state, the court was of the opinion that the issuance of such Order No. 8 was not with the intention to cause injustice to the parties involved. In Order No. 9 of the Practice Direction 2001, the Syariah court in Malaysia agreed to adopt the shari'ah ruling from various schools of Islamic law but at the same time recognizing only the endorsed mazhab in that particular state.

Secondly it is the case of Raja Mohar v. Fara Liza Bt Bashah Raja Chulan Bin (unreported case), where in this case the husband had pronounced triple talaq with the intention to deprive the wife of her right to nafkah (maintenance) as provided by the shari'ah law as the nafkah is not incumbent after a third and final talaq. As

\footnotetext{
25 Ibid, p. 9.

${ }^{26}$ Federal Court's Grounds of Decision for State Government of Negeri Sembilan \& Ors v Muhamad Juzaili Bin Mohd Khamis \& Ors, Criminal Reference Number: 01(f)-8-022015(N) \& 01-7-02/2015(N).
} 
there are no statutory provisions in Malaysia that clearly say that the pronouncement of triple talaq would constitute a three talaq, the court, therefore, ruled that the triple talaq pronounced by the husband is only tantamount to one single talaq in order to avoid injustice to both parties, especially the wife.

Another exercise of judicial activism by the shari'ah court can be evidently seen in the case of Sumathi A/P Maniam v. Majlis Agama Islam Wilayah Persekutuan ${ }^{27}$ where the Shari'ah High Court in the Federal Territory of Kuala Lumpur had ruled that the Shari'ah High Court in this case has jurisdiction to hear and determine an application filed by the applicant to apostatize from Islam after taking into consideration the Ninth Schedule of the Federal Constitution of Malaysia and the previous decisions of the civil courts in Malaysia despite the fact that there is no such law in the federal territories which allows the shari'ah courts to hear and determine an application by a Muslim to apostatize from Islam. After perusing the previous decisions of the civil courts, the Shari'ah High Court held that even though there are no specific laws allowing the shari'ah courts to determine and hear this kind of application, the shari'ah courts still have the jurisdiction to hear and determine the said matter by way of necessary implication as the Ninth Schedule of the Federal Constitution of Malaysia clearly allows the shari'ah courts to adjudicate in matters relating to conversion to Islam and as such, the shari'ah courts should also be allowed to adjudicate matters relating to apostasy.

In addition to that, one could also consider the decision of the Selangor Shari'ah Court of Appeal in Shaiful Hisham Bin Haji Mahat \& Ors v. Mariam Binti Md Rais (unreported case) ${ }^{28}$ whereby in this case the applicants had filed a leave application to file review against the consent judgment endorsed by the Shari'ah High Court as the limitation period of 30 days to file such review has set in. A review application should be filed by the aggrieved party within 30 days from the date of the decision made by the Shari'ah High Court, however unfortunately in this case they took approximately six months before deciding to file a review application in the Shari'ah Court of Appeal and as the limitation period has set in, a leave should be obtained first before the applicants can proceed to file review application. It is to be noted here that there is no specific law that governs the criteria in which leave application should be granted by the court. The Shari'ah Court of Appeal in allowing the leave application filed by the applicants, apart from finding that there were merits in their arguments, had taken into consideration that the applicants at the time of the consent judgment endorsed by the Shari'ah High Court were not being represented by any syar'ie lawyer due to their financial constraint and furthermore, they were also public individuals who have no knowledge of any procedural law and the regulations of the court. Thus the Shari'ah Court of Appeal in this case was of the opinion that leave should be allowed in order to avoid injustices. One could therefore conclude that the Shari'ah Court of Appeal in this case, quite contrary to civil courts, would be more inclined to accept "ignorance of law" as a reasonable excuse.

It is worthy to take note that in these four shari'ah cases, the exercise of judicial activism by the shari'ah courts in Malaysia was done by the male judges. Unfortunately up until today, the authors could not find any judgments which have been delivered by the female shari'ah court judges in any reported cases. This is however not unnatural as the appointment of female shari'ah court judges in Malaysia, as opposed to the appointment of male shari'ah court judges, had only materialised in 2010 for the shari'ah lower court in the Federal Territory of Kuala Lumpur, Malaysia and 2016 for the shari'ah high court in the State of Selangor, Malaysia.

\footnotetext{
27 JH 36 BHG.1 (1434H/2013), 143.

${ }^{28}$ Please refer to the grounds of decisions of the Selangor Shari'ah Court of Appeal in the case of Shaiful Hisham Bin Haji Mahat \& Ors v. Mariam Binti Md Rais (Leave Application No.: 10000-099-0017-2017) dated 23rd January, 2018.
} 
Based on the preceding discussions, one could see how judges apart from having a good conscience and intelligence, judges be it male or female are expected to possess the ability of judicial creativity or judicial activism in order to arrive at a just decision. Without such creativities, the law would be applied rigidly and on certain occasions justice is denied to be served to the parties.

\section{Socio Legal Position in Malaysia and Indonesia}

At this moment, there are two serving Shari'ah High Court female judges in Malaysia. They are now holding offices at the shari'ah courts in the State of Selangor after their appointments were made in $2016 .{ }^{29}$ Actually, back in 2010, there were two first women who were appointed as shari' ah subordinate court judges in the Federal Territory of Kuala Lumpur. As far as fatwa is concerned, in 2006 the National Fatwa Council of Malaysia has issued a decree that woman is allowed to hold the post of judge except in hudud and qisas cases. Since Malaysia is not implementing hudud and qisas punishments, then it is permissible to hold the noble post. As of the year 2017, there are 27 female judges in the shari'ah court in Malaysia (Roslan, 2016). In October 2017, Prof Datuk Seri Zaleha Kamarudin was appointed as one of the Syari'ah Appeal Court judges in Terengganu. This was the first appointment ever at the Syariah appellate court level in Malaysia.

Among the social challenges, female judge is facing the negative perception among the male counterparts about their capability to dispense justice. Many of them associated female judges as being emotional during the trial as compared to the male judges. Department of Shari'ah Judiciary Malaysia has expressed their concern on the first appointment which was made in 2010 that the presence of women on the bench can make a difference because women possess different experiences, concerns, and interests that can bring new perspectives and reduce stereotypes. ${ }^{30}$

In Aceh, there are 15 shari'ah court female judges and three of them are at the superior level. There is no legal provision in Aceh and in Indonesia about gender as one of the qualifications to be a judge. Indonesia, in general, has been in the forefront in acknowledging woman to be a judge as early as 1960s (Nurlelawati \& Salim, 2013). By late 1964, there were 16 female judges in the District Religious Court of Tegal (Nurlelawati \& Salim, 2013). In 2011, it was reported that there 507 female judges throughout Indonesia (Nurlelawati \& Salim, 2013).

According to Ibu Ros ${ }^{31}$, one of Shari'ah Appeal Court judges in Aceh, other than an academic qualification that one should possess, to be a judge one must have full integrity in fulfilling his duties. She further stated that there are three important elements that a judge must scrutinise prior giving judgement: justice, benefits, and certainty of the judgment. She also emphasized that it is indeed important that a judge must be able to familiarise himself or herself with the custom of one’s community prior giving judgement.

\section{Conclusion}

In the judiciary, the most important element is good governance and justice. In Al-Quran Surah aal Imran, Verse 104, Allah said to the effect:

And let there be [arising] from you a nation inviting to [all that is] good, enjoining what is right and forbidding what is wrong, and those will be the successful. (Allah)

\footnotetext{
${ }^{29}$ The Malay Mail, June 27th, 2016.

30 The Star Online, July 27th, 2010.

31 Through email correspondence with her on February 18th, 2018.
} 
This verse emphasizes that there should be a group of people who will enjoin what is good and forbid what is evil and wrong in a community regardless of whether they are man or woman. What is important in the judiciary are the ability, creativity, and skills to serve justice to the people. The ability to serve justice depends on his knowledge and past experience in handling cases and problems in his life. Malaysia is a bit late in empowering a woman to be a judge in the shari'ah court but that does not mean the authority did not acknowledge the position of woman in the aspect of the judicial institution. A Muslim woman, on the other hand, has contributed a lot in developing the country especially in educating the generation and nation in their own way. On a different note, one must remember that Islamic law has to look at two different stages: development and interpretation. Islamic law is developed through a set of legal texts as well as the traditions of the Prophet SAW. At the same time, one must remember Islamic law is interpreted and practised through the norms of a community and circumstances at that particular time.

\section{References}

Al-Alwani, T. J. (1993). Ijtihad. London, UK: International Institute of Islamic Thought.

Doi, A. R. I. (1984). Shari'ah: The Islamic law. Kuala Lumpur, Malaysia: A. S. Noordeen.

Easterbrook, F. H. (2002). Do liberals and conservatives differ in judicial activism? University of Colorado Law Review, 73, 1401-1416.

Kmiec, K. D. (2004). The origin and current meanings of judicial activism. California Law Review, 92(5), 1441-1478.

Hishamudin Yunus, M. (2011). Judicial activism-The way to go. The Malaysian Judiciary.

Nurlelawati, E., \& Salim, A. (2013). Gendering the Islamic judiciary: Female judges in the religious courts of Indonesia. Al-Jami'ah Journal of Islamic Studies, 51(2), 247-278.

Pinelli, C. (2007). The concept and practice of judicial activism in the experience of some western constitutional democracies. Juridica International, (2), 31-37.

Prakash, B. (2002). Sociolegal status of women in Indonesia, Malaysia, Philippines and Thailand. Retrieved from http://hdl.handle.net/11540/3018

Ramadan, S. (1987). Islamic law: Its scope and equity. Kuala Lumpur, Malaysia: Muslim Youth Movement of Malaysia.

Ringhand, L. A. (2007). Judicial activism: An empirical examination of voting behaviour on the rehnquist natural court. Constitutional Commentary, 24, 43-95.

Roslan, N. H. (2016). The appointment of women as Syariah court judges in Malaysia. Paper presented at Seminar on Women as Judges and Leaders, International Advance of Islamic Studies, 19th July, 2016.

Rozlan, A. M. (2017). Judicial activism in Malaysia: Selected fundamental human rights issues (Dissertation, University of Malaya, Kuala Lumpur, Malaysia).

Shentob, Z. B. (2001). Following Thayer: The conflicting models of judicial restraint. Boston University Public Interest Law Journal, 21(1). Retrieved from http://ssrn.com/abstract=2029687

Wan Muhammad, R. (2009). Shariah court judges and judicial creativity in Malaysia and Thailand. Journal of Muslim Minority Affairs, 29(1), 127-139. 